\title{
5. The Duty of Care: The Right to Health in Hospital Settings
}

'1) The right of everyone to the enjoyment of the highest attainable standard of physical and mental health.

2c) The prevention, treatment and control of epidemic, endemic, occupational and other diseases.

$2 d)$ the creation of conditions which would assure to all medical service and medical attention in the event of sickness.'

- Article 12 of the International Covenant on Economic, Social and Cultural Rights

The role of the public hospital in the context of AIDS care is inarguably a State responsibility. National programmes traditionally acknowledge this by investing in staff training, including stigma reduction. This has not proven effective in many settings, as an examination of the narratives amply demonstrates.

L's experience in Jamaica as he nursed his partner are painful:

'At that time people used to be kept on specific wards. They were not looked on by the nurses, the doctors. They didn't want to touch them, they were scorned. They were basically like the Biblical days about people having leprosy, so persons were not treated well. It would have been stressing even to go to the hospital to disclose I am HIV-positive. People are still afraid of talking about their HIV status or disclosing to medical professionals.

'I think he was afraid if he got sick what would happen to him if he needed to go to the hospital. He wouldn't get better treatment at the hospital. Eventually when he got sick and went to the hospital he didn't get good treatment. As an individual living with the virus he had gone to the doctor's before. The treatment he received made him never want to go to the hospital again.

'I do not think he was in the hospital long because I had gone and visited him maybe three or four days earlier at home. I did not know he was in the hospital because apparently what happened is that he went to Spanish Town Hospital and they transferred him to Kingston Public Hospital. Someone from the yard, one of the neighbours, got him to Spanish Town Hospital. Then I did not even know when he went into the hospital. I was at work one day and someone called me and told me that my friend had died. He was on Ward 9. Ward 9 was where persons with HIV were being kept or bedded.' 
In this case, the State failure to guarantee dignity, rights and freedoms equally to all citizens was violated because these were gay men. They lived in such fear with the stigma of both their sexuality and their HIV status that they were too afraid to seek the public health care and support to which other citizens were entitled for other illnesses as a matter of course. They constantly lived in a state of stress with the conditions of HIV, and could not enjoy equal human rights. Furthermore, Jamaica did not create the conditions that assured them of medical service and medical attention in the event of HIV.

In Papua New Guinea, Alice recounts taking her sister's husband (and later her sister) to the doctor:

'...with what looked like scabies spread everywhere. Under his skin and into his body too. We went to the skin doctor at the hospital to get medicine and cream. It didn't get better. His skin was looking worse and then his joints locked up and he couldn't walk properly. Finally he couldn't walk at all. He was losing a lot of weight. We went to Three Mile and they admitted him to Port Moresby General Hospital. My sister looked after him and I watched the kids at home. The doctors discharged him and they came home. We returned to the village and he died there.

'My sister looked after her husband in the hospital. .... While caring for him she got the scabies. He passed it on to her and she started to get sick. The sores were spreading and she went to the skin doctor to get cream. ... The sores were getting bigger. This continued until I saw that she was really bad and there was nothing more I could do to help so I took her to the hospital. They said TB. But when I talked to the TB doctors they said "no, it's not TB". We were in emergency and she was very weak and said she couldn't hold on anymore. She died in the hospital. ... They did blood tests when they first went in and said that he was not sick. One doctor said $\mathrm{TB}$ and referred us to the TB clinic but the TB doctor said it was not TB. He said it was a different sickness. But they never told us what sickness it was.'

Ruth, B's mother recounts:

'My daughter was living at home with me when she got sick. I took her to the Barracks Clinic, which is about a mile from our house. They said she had malaria and pneumonia. It was only later I heard from others that she had HIV/AIDS. I took her to the AIDS clinic. I would go to the Barracks Clinic and ask for medicine. If they had none, I had to find money and go to the pharmacy to try and buy medicine. Medicine was expensive. Some were 20 kina, 30 kina, some were almost 45 . When I didn't have enough money I would try to get the 30 kina packet. Some people who work with HIV patients came and told me that the best thing would be for me to take her and leave her with them at the AIDS Clinic at Six Mile. But I heard that they mistreat them. They shout and swear at them 
and treat them badly. I heard that they push them in the showers so they fall down. Because of these stories I said no to them. The sisters at Taurama Barracks Clinic also advised me to take her to the AIDS hospital. I don't treat my child badly. Why should I send her to where strangers might?

'I never found any support in the way of counselling. I didn't know where to go. When she got really sick we paid for the ambulance from fish money and took her to the hospital. After we went back to the village we didn't see anyone from the hospital again. They knew about us. But no one came to help us. After she died people from the AIDS clinic came and did a workshop here.'

When Papua New Guinea and any other State ratifies the ISESCR, they agree that everyone is entitled to the highest attainable standard of physical and mental health. In the stories of Alice and Ruth:

- $\quad$ HIV conditions were wilfully misdiagnosed by State agents who were members of the medical profession

- information was deliberately withheld from the patient and the carer

- there was no outreach support or information for the carer, and

- medicine was not provided, further impoverishing the household.

The final irony is the State arrives to discharge its duties after the patient has died.

M, who nursed her sister in a public hospital in Guyana tells her story:

'She was sitting in the chair and she said "you know, I can't make it. Carry me to the hospital". By the time we went to the hospital and to check her up and do the test they told me she was HIV-positive. She could not have walked. They were not admitting her at the hospital. They told me to take her back home. While we were trying to get her out of the hospital she collapsed. Her foot give out. And then they say to come back and they admit her. I was confused because hearing she was HIV-positive then they not wanting to keep her at the hospital.

'So when I left the hospital they say you have to bring things for the hospital. I used to go. The first day I went I cleaned her skin. And just like how I leave her, the nurse left her there. And for the two weeks that she spent in the hospital the nurses have never ever done anything for her. They just put her there to the last bed in the ward in the corner. At first they gave her some saline for the first two days. And then they took out the saline and if I don't go in time to clean her skin she would be left there until I go. So I had to be there three times a day to clean her skin. The nurses 
have done nothing for her in hospital. I have never seen a doctor because when I get there they would always say the doctor done run the ward and because of the fact that she wasn't seeing and she was not talking, I could not have asked her if the doctor was there. But I have never seen the doctor.

'I fed her, I used to feed her in the morning and at lunch time. Liquids. I used to have a straw but she had this thrush in her mouth. The diarrhoea it only happened for two days before she died.

'I am still wondering, sometimes I am being in denial, did my sister really die from HIV? With all the signs and symptoms she didn't have diarrhoea, she didn't have vomiting, she did not have sores, and I still can't come to grips with it. I think there is a lesson that people out there should learn. That the nurses would not do what a caregiver would do.'

It is common for hospitals not to want to admit people with AIDS and to want to discharge them, which breaches article 12 of the ICESCR. The need for carers to continue to care even when the patient is hospitalised because of the failure of the State to provide sufficient care is also in evidence. This too is not unusual. No carer is free from stress and the implications for their own mental health because the member of their family has been hospitalised. Full information, and access to anyone who might provide that, was also denied. As a consequence the carer worries after the death whether or not they did something wrong. 